\title{
Similar interstitial deletions of the KAL-1 gene in two Brazilian families with X-linked Kallmann Syndrome
}

\author{
Ericka Barbosa Trarbach ${ }^{1}$, Isabella Lopes Monlleo $^{2}$, Carlos Guilherme Gaelzer Porciuncula ${ }^{3}$, Marshall Italo \\ Barros Fontes $^{2}$, Maria Teresa Mathias Baptista ${ }^{4}$ and Christine Hackel ${ }^{1,5}$ \\ ${ }^{1}$ Universidade Estadual de Campinas, Centro de Biologia Molecular e Engenharia Genética, \\ Laboratório de Genética Humana, Campinas, SP, Brazil. \\ ${ }^{2}$ Universidade de Ciências da Saúde de Alagoas, Faculdade de Medicina, Departamento de Pediatria, \\ Maceió, AL, Brazil. \\ ${ }^{3}$ Universidade Federal de Alagoas, Centro de Ciências da Saúde, Departamento de Toco-Ginecologia \\ e Pediatria, Maceió, AL, Brazil. \\ ${ }^{4}$ Universidade Estadual de Campinas, Hospital das Clinicas, Departamento de Clínica Médica, \\ Campinas, SP, Brazil. \\ ${ }^{5}$ Universidade Estadual de Campinas, Faculdade de Ciências Médicas, Departamento de Genética Médica, \\ Campinas, SP, Brazil.
}

\begin{abstract}
Mutations in the KAL-1 gene localized at Xp22.3 have been shown to be responsible for the X-linked Kallmann syndrome (KS), a disorder characterized by the association of hypogonadotropic hypogonadism and anosmia. In this paper, we describe the investigation of two families with $\mathrm{X}$-linked $\mathrm{KS}$, in which similar interstitial deletions spanning exons 5 to 10 of the $K A L-1$ gene were identified. The presence of interspersed repetitive DNA sequences within the $K A L-1$ gene might have predisposed to this type of mutation.
\end{abstract}

Key words: X-linked KS, intragenic deletions, KAL-1 gene, PCR, phenotypic variability.

Received: July 5, 2003; Accepted: February 16, 2004.

\section{Introduction}

Kallmann syndrome (KS) is a disorder defined by the association of hypogonadotropic hypogonadism with anosmia or hyposmia (Kallmann et al., 1944) that is due to a neuronal migration defect involving both the gonadotropin-releasing hormone $(\mathrm{GnRH})$ and the olfactoryproducing neurons (Schwanzel-Fukuda et al., 1989). Although the majority of KS cases are sporadic, segregation analysis in familial cases revealed X-linked, as well as autosomal recessive and autosomal dominant modes of transmission, indicating genetic heterogeneity (Hermanussen and Sippell, 1985; Chaussain et al., 1988; Waldstreicher et al., 1996).

The $K A L-1$ gene responsible for the $\mathrm{X}$-linked form of KS (MIM 308700) was mapped to Xp22.3 by linkage analysis and deletion studies (Ballabio et al., 1989; Petit et al.,

Send correspondence to Christine Hackel. Universidade Estadual de Campinas, Laboratório de Genética Humana, Caixa Postal 6010, 13083-970 Campinas, SP, Brazil. E-mail: hackel@ unicamp.br.
1990) and was subsequently isolated by different positional cloning strategies (Franco et al., 1991; Legouis et al., 1991). This gene consists of 14 exons spanning approximately $210 \mathrm{~kb}$ (Del Castillo et al., 1992) and encodes a protein, anosmin-1, that contains four fibronectin type III repeats and a putative protease inhibitor domain, structural features found in several cell and substrate adhesion molecules (Franco et al., 1991; Legouis et al., 1991). This raises the possibility that anosmin-1 could function in the migration of GnRH-secreting neurons and olfactory axons, during embryonic development (Franco et al., 1991; Legouis et al., 1991; Rugarli et al., 1996).

In addition to hypogonadism and anosmia, a variety of other defects occur in patients with X-linked KS. They include neurological deficits such as bimanual synkinesis (Kallmann et al., 1944; Sunohara et al., 1986), cerebellar dysfunction, nystagmus (Sunohara et al., 1986; Schwankhaus et al., 1989), mental retardation (Kallmann et al., 1944; Wegenke et al., 1975), hearing loss (White et al., 1983), and somatic defects, such as unilateral renal agenesis, pes cavus and high-arched palate (White et al., 
1983; Schwankhaus et al., 1989; Zenteno et al., 1999). Some of these symptoms (e.g. synkinesis and renal agenesis) are more frequently observed in patients with $\mathrm{X}$-linked KS, indicating that these features represent pleiotropic effects of mutations in the $K A L-1$ gene (Hardelin et al., 1993) and suggesting a more generalized role of this gene during development, involving the nervous system and non-neuronal tissues (Hardelin et al., 1992,1993).

In this paper, we report two unrelated Brazilian families with X-linked $\mathrm{KS}$ and similar interstitial deletions spanning exons 5 to 10 of the $K A L-1$ gene.

\section{Subjects and Methods}

\section{Patient reports}

We studied two unrelated families with KS-affected males. In family 1 (Figure 1A), from Arapiraca, state of Alagoas, northeastern Brazil, five males were clinically evaluated (II-6, III-4, III-7, III-12, and IV-6), and in family 2 (Figure 1B), from Campinas, state of São Paulo, south-

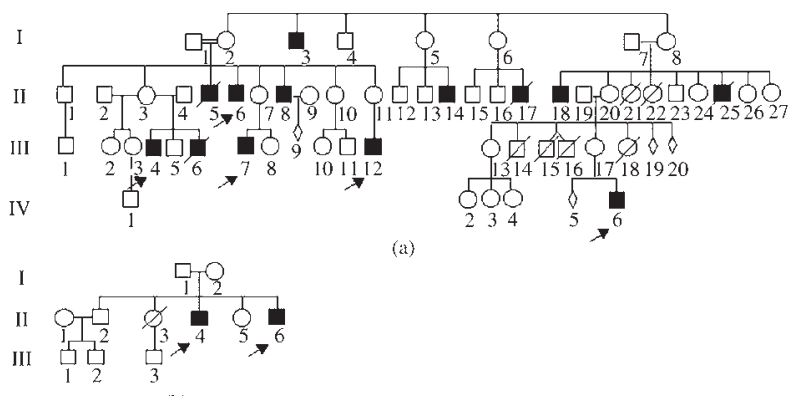

(b)

Figure 1 - Heredograms of (a) family 1 and (b) family 2 with X-linked KS. Affected males. Arrows indicate patients clinically examined in this study. eastern Brazil, two affected brothers (II-4 and II-6) were examined. In family 1 , X-linked inheritance of KS was assumed, based on the presence of asymptomatic female carriers, the presence of at least two affected males in the maternal family or among male siblings, the absence of affected females and the absence of male-to-male transmission. In family 2, X-linked inheritance of KS was suspected because one of the affected patients had a renal abnormality.

Laboratory testing was performed in all patients, revealing low levels of testosterone, FSH (folliclestimulating hormone) and LH (luteinizing hormone), consistent with hypogonadism. Formal olfactory testing was not performed, but anosmia was detected in the individuals II-6, III-4 (Family 1) and II-4 (Family 2) by direct inquiry. Clinical evaluation details of all patients are given in Table 1. The protocol was approved by the Ethics Committee of the State University of Campinas (UNICAMP) School of Medicine. Informed consent was obtained from all subjects included in this study.

\section{Molecular analysis of the $K A L-1$ gene}

Genomic DNA of individuals II-11, III-4 and III-17 (Family 1), I-2, II-4 and II-6 (Family 2) was extracted from peripheral leukocytes, using the phenol/chloroform method. The 14 coding exons of the KAL-1 gene were amplified by PCR from DNA of the affected males, patients III-4 (Family 1), II-4 and II-6 (Family 2). The sequences of primers and the size of the amplified products were as previously described by Hardelin et al. (1993). PCR amplifications were performed in $50 \mu \mathrm{L}$ reaction mixes containing 200-500 ng of genomic DNA, $0.2 \mathrm{mM}$ dNTPs, $1.5 \mathrm{mM}$ of $\mathrm{MgCl}_{2}, 0.6 \mathrm{pmol}$ of each of the primers, $1 \mathrm{x}$ PCR buffer, and $1 \mathrm{U}$ Taq polymerase. After a first denaturation step (10 min,

Table 1 - Clinical features of evaluated patients from families 1 and 2 with X-linked KS.

\begin{tabular}{|c|c|c|c|c|c|c|c|c|}
\hline Patient & Age & $\begin{array}{l}\text { Anosmia/ } \\
\text { hyposmia }^{\mathrm{a}}\end{array}$ & $\begin{array}{c}\text { Hypogonadotropic } \\
\text { hypogonadism }\end{array}$ & $\begin{array}{c}\text { Micropenis/ } \\
\text { Cryptorchidism }\end{array}$ & $\begin{array}{l}\text { Bimanual } \\
\text { synkinesis }\end{array}$ & $\begin{array}{c}\text { Renal } \\
\text { abnormality }\end{array}$ & $\begin{array}{c}\text { Other } \\
\text { characteristics }\end{array}$ & $\begin{array}{l}\text { MRI of olfactory } \\
\text { structures }\end{array}$ \\
\hline II-6* & $32 \mathrm{y}$ & Yes & Yes & Yes & Yes & No & $\begin{array}{l}\text { High-arched palate } \\
\text { Genu valgum } \\
\text { Eunuchoid habitus }\end{array}$ & Not performed \\
\hline III-4* & $20 \mathrm{y}$ & Yes & Yes & Yes & Yes & $\begin{array}{l}\text { Agenesis at left } \\
\text { side }\end{array}$ & $\begin{array}{l}\text { High-arched palate } \\
\text { Genu valgum } \\
\text { Eunuchoid habitus }\end{array}$ & $\begin{array}{l}\text { Bilateral aplasia of } \\
\text { sulcus and rudimen- } \\
\text { tary bulbs }\end{array}$ \\
\hline III-7* & $6 y$ & $?$ & Yes & Yes & Yes & No & High-arched palate & Not performed \\
\hline III-12* & $4 \mathrm{mo}$ & $?$ & Yes & Yes & $?$ & No & & Not performed \\
\hline IV $-6^{*}$ & $4 \mathrm{mo}$ & $?$ & Yes & Yes & $?$ & No & $\begin{array}{l}\text { Epicanthal folds Bi- } \\
\text { lateral ptosis of eye- } \\
\text { lids Asymmetric ears }\end{array}$ & Not performed \\
\hline II-4\# & $35 \mathrm{y}$ & Yes & Yes & Yes & No & No & Gynecomastia & Not performed \\
\hline II-6\# & $28 \mathrm{y}$ & No & Yes & Yes & No & $\begin{array}{l}\text { Horseshoe kidney } \\
\text { on right side }\end{array}$ & Mental retardation & Not performed \\
\hline
\end{tabular}

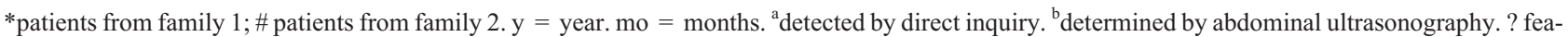
tures not evaluated due to patient age. 
$95{ }^{\circ} \mathrm{C}$ ), 30 PCR amplification cycles of $1 \mathrm{~min}$ at $95^{\circ} \mathrm{C}$, $1 \mathrm{~min}$ at $57{ }^{\circ} \mathrm{C}$ (except for exon $1,60^{\circ} \mathrm{C}$ ), and $2 \mathrm{~min}$ at $72{ }^{\circ} \mathrm{C}$ were carried out, followed by a final extension of $10 \mathrm{~min}$ at $72{ }^{\circ} \mathrm{C}$. The PCR products were electrophoresed on $1.5 \%$ agarose gel, stained with ethidium bromide and photographed. If no amplification product of $K A L-1$ exons was detected, PCR was repeated with the addition of primers SRY1 and SRY4 for the SRY gene (Assumpção et al., 2002) as internal positive control.

Comparative duplex PCR for carrier female status determination was performed, following the procedure described by Nagata et al. (2000), in subjects II-11 and III-17 (Family 1) and I-2 (Family 2), mothers of affected males. The reactions included primers for exon 20 of the autosomal $\mathrm{NPCl}$ gene as internal standard to quantify the dosage of $K A L-1$ exon 7 PCR products. The amplified products were analyzed by electrophoresis on $2.6 \%$ agarose gel stained with ethidium bromide, and the gel image was captured with a Kodak Digital Science DC120 camera. The intensity of each band was measured using 1D IMAGE ANALYSIS software, and the gene dosage was evaluated by the $K A L-1 / N P C 1$ ratio. Samples from normal males $(\mathrm{n}=10)$ and females $(\mathrm{n}=10)$ were also run as controls. The expected values were $0.0,0.5$, and 1.0 for affected males, carrier females and normal males, and normal females, respectively.

\section{Results}

The genomic DNA from patients III-4 (Family 1), II-4 and II-6 (Family 2) did not yield PCR products from exon 5 to exon 10, while the remaining exons were amplified. These findings indicate the presence of an interstitial deletion encompassing exons 5-10 in the $K A L-1$ gene of these patients (Figure 2).

By duplex PCR, the status of obligatory carrier females was confirmed in subjects II-11 and III-17 (Family 1) and I-2 (Family 2). In these females, the KAL-1/NPC1 ratios were $0.53,0.54$ and 0.47 , respectively, indicating the presence of only one normal $K A L-1$ allele. In the control subjects, the $K A L-1 / N P C 1$ ratios were next to 0.5 for males and 1.0 for females (Figure 3).

\section{Discussion}

We describe here two interstitial deletions of the $K A L-1$ gene encompassing exons 5-10 in two unrelated and geographically distant Brazilian families. Although molecular analysis by PCR was performed in only one patient from Family 1, the causative role of the $K A L-1$ gene for KS in this family was confirmed by the demonstration of the carrier status of the mothers of patients III- 12 and IV-6. Additional symptoms found in the five clinically examined affected males of this family included bimanual synkinesis (3/5), renal agenesis (1/5), high-arched palate (3/5), and dysmorphic facial features (1/5). In Family 2 , molecular in-
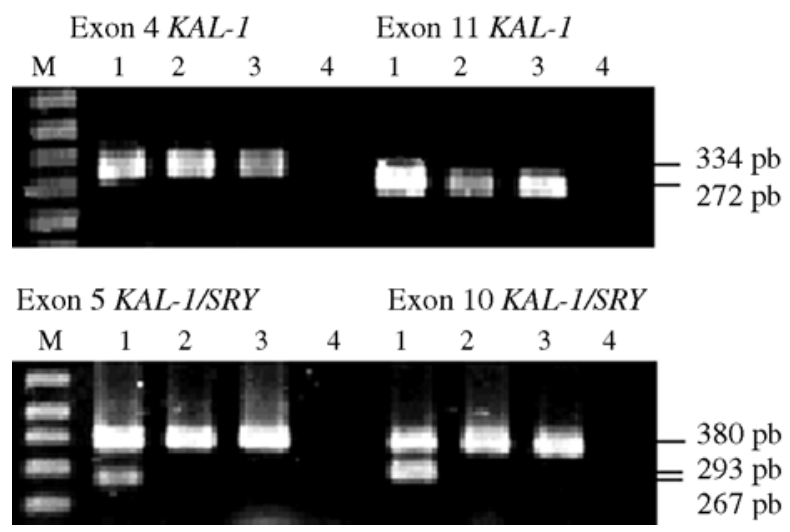

Figure 2 - PCR amplification of exons 4 (334 bp), 5 (267 bp), 10 (293 bp), and $11(272 \mathrm{bp})$ of the $K A L-1$ gene in two patients affected by X-linked KS. Lanes 1-4 correspond, respectively, to a normal 46,XY male, patient III-4 (Family 1), patient II-6 (Family 2), and a negative control with omission of the genomic DNA in the PCR. Lane M: molecular weight marker. Exons 4 and 11 (a) may be amplified in the three males (lanes 1-3), whereas exons 5 and 10 are amplified only in the control male (lane 1). For exons 5 and 10 (b), a product of the $S R Y$ gene (internal positive control, $380 \mathrm{bp}$ ) can also be visualized.

vestigation of the $K A L-1$ gene was performed in both patients, and the carrier status of their mother was also demonstrated. One of these patients had mental retardation and a horseshoe right kidney in association with KS.

Nagata et al. (2000) described two brothers with $\mathrm{X}$-linked KS due to a deletion of exons 5-10 of the KAL-1 gene, but neither mental retardation nor bimanual synkinesis were reported to be present. In fact, mental retardation is rarely observed in patients with isolated $\mathrm{KS}$, but has been described in patients affected by associations of several diseases linked to Xp22.3, as contiguous gene syndromes (Meindl et al., 1993; Weissortel et al., 1998). Bimanual synkinesis is one of the most frequent findings and is considered a marker for X-linked KS (Krams et al., 1999; Quinton et al., 2001), with an estimated prevalence

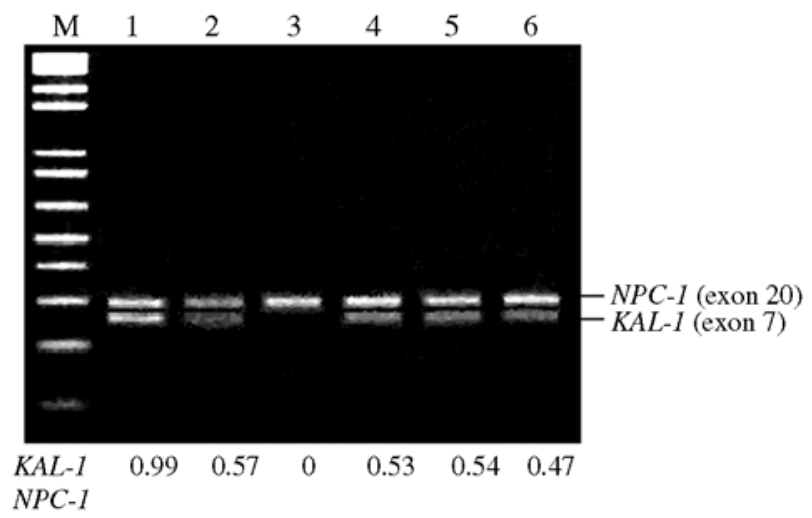

Figure 3 - Comparative duplex PCR for identification of carrier females. Lanes: 1 - control female; 2 - control male; 3-5 - individuals from family 1, respectively, III-4 (affected male), II-11 and III-17 (mothers of patients III-12 and IV-6); and 6 - individual I-2 from family 2 (mother of patients II-4 and II-6). M - molecular weight marker. Values for the $K A L-1 / N P C I$ ratio are given below each lane. 
of $85 \%$ among X-KS patients (MacColl et al., 2002). However, in a recent report on a family with a mutation in the FRGR1 gene (KAL-2), mapped to 8p, bimanual synkinesis was observed, suggesting that this feature should not be considered specific to the X-linked form (Dodé et al., 2003).

Several small deletions, point mutations and a few single-exon deletions have been identified in the KAL-1 gene in patients with KS (Hardelin et al., 1992; Parenti et al., 1995; Georgopoulus et al., 1997; Quinton et al., 1996; Söderlund et al., 2002). Large deletions involving more than one exon of $K A L-1$ have been reported for exons 13-14 (Bick et al. (1992), 3 to 5 (Maya-Nunez et al., 1998), 5 to 10 (Nagata et al., 2000), and 3 to 13 (Massin et al., 2003). Although the breakpoints were not determined in most cases, it is possible that intronic regions flanking these deletions contain repeated elements that might promote nonallelic recombination. We used the RepeatMasker software (http:// ftp.genome.washington.edu/cgi-bin/RepeatMasker", accessed 9/16/2003) for repeat identification in the intronic sequences between exons 4-5 and 10-11 of KAL-1. Elements of a FLAM_A repeat of the Alu family were found in both introns on opposite strands (Figure 4a). Although no similarity was found between these two elements using BLAST (, accessed 10/7/2003), a significant similarity score was detected for a short sequence of 51 nucleotides when the whole intronic sequences were compared (Figure $4 b)$. This short sequence is contained in the FLAM_A repeat in intron 10 and is adjacent to the FLAM_A repeat in intron 4 . These analyses failed to detect other repeats with remarkable sequence identity that could mediate illegitimate recombination events.

In the deletion of exons 13-14 described by Bick et al. (1992), sequencing of the junction fragments revealed a 6 bp homology motif (CAAATT) at the deletion breakpoints. These short stretches of sequence homology have been suggested to facilitate end-joining in recombination events in several regions of the genome (Krawczak and Cooper, 1991; Woods-Samuels et al., 1991). It is noteworthy that copies of this $6 \mathrm{bp}$ motif are present in the intronic se-
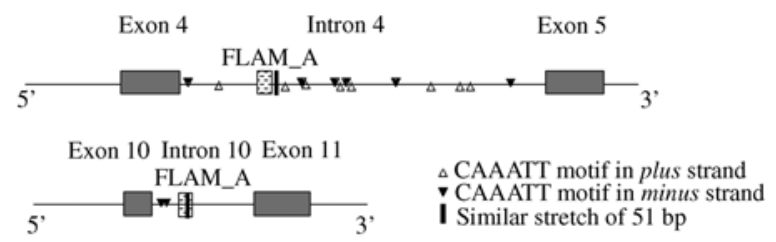

(a)

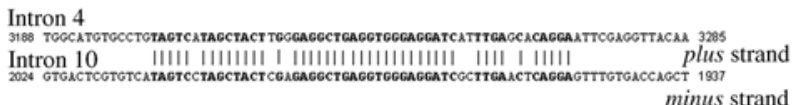

(b)

Figure 4 - (a) Relative positions of FLAM_A Alu repeats and CAAATT motifs on introns 4 and 10 of the $K A L-1$ gene, and (b) alignment of the similar 51 bp stretch (E value: 2e-04). quences flanking the 5-10 deletion (Figure 4a). Thus, at least two different molecular mechanisms may be responsible for the observed intragenic deletion. Together with the similar deletion previously described by Nagata et al. (2000), our data suggest that a recurrent mechanism could predispose to this specific large exon-type deletion.

\section{Acknowledgments}

EBT was supported by a fellowship from Fundação de Amparo à Pesquisa do Estado de São Paulo (FAPESP: 00/08834-8). We also thank FAPESP for grants received for the development of this research.

\section{References}

Assumpção JG, Benedetti CE, Maciel-Guerra AT, Guerra Jr G, Baptista MT, Scolfaro MR and De Mello MP (2002) Novel mutations affecting SRY DNA-binding activity: The HMG box $\mathrm{N} 65 \mathrm{H}$ associated with $46, \mathrm{XY}$ pure gonadal dysgenesis and the familial non-HMG box R30I associated with variable phenotypes. J Mol Med 80:782-90.

Ballabio A, Bardoni B, Carrozzo R, Andria G, Bick D, Campbell B, Hamel B, Ferguson-Smith MA, Gimelli G, Fraccaro M, Maraschio P, Zuffardi O, Guioli S and Camerino G (1989) Contiguous gene syndromes due to deletions in the distal short arm of the human X chromosome. Proc Natl Acad Sci USA 86:10001-10005.

Bick D, Franco B, Sherins RJ, Heye B, Pike L, Crawford J, Maddalena A, Incerti B, Pragliola A, Meitinger $\mathrm{T}$ and Ballabio A (1992) Intragenic Deletion of the $K A L-1$ gene in Kallmann's syndrome. New Engl J Med 326:1752-1755.

Chaussain JL, Toublanc JE, Feingold J, Naud C, Vassal J and Job JC (1988) Mode of inheritance in familial cases of primary gonadotropic deficiency. Horm Res 29:202-206.

Del Castillo I, Cohen-Salmon M, Blanchard S, Lutfalla G and Petit C (1992) Structure of the X-linked Kallmann syndrome gene and its homologous pseudogene on the $\mathrm{Y}$ chromosome. Nat Genet 2:305-310.

Dodé C, Leilliers J, Dupont J-M, De Paepe A, Dû NL, SoussiYanicostas N, Coimbra RS, Delmaghani S, CompainNouaille S, Baverel F, Pêcheaux C, Le Tessier D, Cruaud C, Delpech M, Speleman F, Vermeulen S, Amalfitano A, Bachelot Y, Bouchard P, Cabrol S, Carel J-C, Delemarrevan der Waal H, Goulet-Salmon B, Kottler A-L and Richard O (2003) Loss-of-function mutations in FGFR1 cause autosomal dominant Kallmann syndrome. Nat Genet 33:463465.

Franco B, Guioli S, Pragliola A, Incerti B, Bardoni B, Tonlorenzi R, Carrozzo R, Maestrini E, Pieretti M, Taillon-Miller P, Brown CJ, Willard HF, Lawrence C, Persico MG, Camerino G and Ballabio A (1991) A gene deleted in Kallmann's syndrome shares homology with neural cell adhesion and axonal path-finding molecules. Nature 353:529-536.

Georgopoulos NA, Pralong FP, Seidman CE, Seidman JG, Crowley WF Jr and Vallejo M (1997) Genetic heterogeneity evidenced by low incidence of $K A L-1$ gene mutations in sporadic cases of gonadotropin-releasing hormone deficiency. J Clin End Metab 82:213-217.

Hardelin JP, Levilliers J, Blanchard S, Carel J-C, Leutenegger M, Pinard-Bertellettom J-P, Bouloux P and Petit C (1993) Het- 
erogeneity in the mutations responsible for X chromosomelinked Kallmann syndrome. Hum Mol Genet 2:373-377.

Hardelin JP, Levilliers J, Del Castillo I, Cohen-Salmon M, Legouis R, Blanchard S, Compain S, Bouloux P, Kirk J, Mouraine C, Chaussin J-L, Weissenbach J and Petit C (1992) X chromosome-linked Kallmann syndrome: Stop mutations validate the candidate gene. Proc Natl Acad Sci USA 89:8190-8194.

Hermanussen M and Sippell WG (1985) Heterogeneity of Kallmann's syndrome. Clin Genet 28:06-111.

Kallmann FJ, Schoenfeld WA and Barrera SE (1944) The genetic aspects of primary eunuchoidism. Am J Ment Defic 48:203-236.

Krams M, Quinton R, Ashburner J, Friston KJ, Frackowiak RSJ, Bouloux P-MG and Passingham RE (1999) Kallmann's syndrome: Mirror movements associated with bilateral corticospinal tract hypertrophy. Neurology 52:816-822.

Krawczak M and Cooper DN (1991) Gene deletions causing human genetic disease: Mechanism of mutagenesis and the role of the local DNA sequence environment. Hum Genet $86: 425-441$.

Legouis R, Hardelin JP, Levilliers J, Claverie J-M, Compain S, Wunderle V, Millasseau P, Le Paslier D, Cohen D, Caterina D, Bougueleret L, Dlemarre-van der Waal H, Lutfalla G, Weissenbach J and Petit C (1991) The candidate gene for the $\mathrm{X}$-linked Kallmann syndrome encodes a protein related to adhesion molecules. Cell 67:423-435.

MacColl G, Bouloux P and Quinton R (2002) Kallmann syndrome: Adhesion afferents and anosmia. Neuron 34:675678.

Massin N, Pêucheux C, Eliot C, Bensinmon J-L, Galey J, Kuttenn F, Hardelin J-P, Dodé C and Touraine P (2003) X chromosome-linked Kallmann syndrome: Clinical heterogeneity in three siblings carrying an intragenic deletion of $K A L-1$ gene. J Clin Endocrinol Metab 88:2003-2008.

Maya-Nunez G, Zenteno JC, Ulloa-Aguirre A, Kofman-Alfaro, S and Mendez JP (1998) A recurrent missense mutation in $K A L-1$ gene in patients with X-linked Kallmann's syndrome. J Clin Endocrinol Metab 83:1650-1653.

Meindl A, Hosenfeld D, Bruckl W, Schuffenhauer S, Jenderny J, Bacskulin A, Oppermann HC, Swensson O, Bouloux P and Meitinger T (1993) Analysis of a terminal Xp223 deletion in a patient with six monogenic disorders: Implications for the mapping of X linked ocular albinism. J Med Genet 30:838842.

Nagata K, Yamomoto T, Chikumi H, Ikeda T, Yamamoto H, Hashimoto K, Yoneda K, Nanba E, Ninomiya H and Ishitobi $\mathrm{K}$ (2000) A novel interstitial deletion of $K A L-1$ in a Japanese family with Kallmann syndrome. J Hum Genet 45:237-240.

Parenti G, Rizzolo MG, Ghezzi M, Di Maio S, Sperandeo MP, Incerti B, Franco B, Ballabio A and Andria G (1995) Variable penetrance of hypogonadism in a sibship with Kallmann syndrome due to a deletion of the KAL gene. Am J Med Genet 37:476-478.
Petit C, Levilliers J and Weissenbach J (1990) Long-range restriction map of the terminal part of the short arm of the human X chromosome. Proc Natl Acad Sci USA 80:3680-3684.

Quinton R, Duke VM, Priyal A, Zoysa PA, Platis AD, Valentine, A, Kendall B, Pickman S, Kirk JMW, Besser GM, Jacobs HS and Bouloux PMG (1996) The neuroradiology of Kallmann's syndrome: A genotypic and phenotypic analysis. J Clin Endocr Metab 81:3010-3117.

Quinton R, Duke VM, Robertson A, Kirk JM, Matfin G, de Zoysa PA, Azcona C, MacColl GS, Jacobs HS, Conway GS, Besser M, Stanhope RG and Bouloux PM (2001) Idiopathic gonadotrophin deficiency: Genetic questions addressed through phenotypic characterization. Clin Endocrinol 55:163-174.

Rugarli EI, Ghezzi C, Valsecchi V and Ballabio A (1996) The Kallmann syndrome gene product expressed in COS cells is cleaved on the cell surface to yield a diffusible component. Hum Mol Genet 5:1109-1115.

Schwankhaus JD, Currie J, Jaffe MJ, Rose SR and Sherins RJ (1989) Neurologic findings in men with isolated hypogonadotropic hypogonadism. Neurology 39:223-226.

Schwanzel-Fukuda M, Bick D and Pfaff DW (1989) Luteinizing hormone-releasing hormone (LHRH)-expressing cells do not migrate normally in an inherited hypogonadal (Kallmann) syndrome. Mol Brain Res 6:311-326.

Söderlund D, Canto P and Méndez JP (2002) Identification of three novel mutations in the $K A L-1$ gene in patients with Kallmann syndrome. J Clin End Metab 87:2589-2592.

Sunohara N, Sakuragawa N, Satoyoshi E, Tanae A and Shapiro LJ (1986) A new syndrome of anosmia ichthyosis hypogonadism and various neurological manifestations with deficiency of steroid sulfatase and arylsultase C. Ann Neurol 19:74-181.

Waldstreicher J, Seminara SB, Jameson JL, Geyer A, Nachtigall LB, Boepple PA, Holmes LB and Crowley WF Jr (1996) The genetic and clinical heterogeneity of gonadotropinreleasing hormone deficiency in the human. J Clin Endocrinol Metab 8:4388-4395.

Wegenke JD, Vehling DT, Wear JB Jr, Gordon ES, Bargman GJ, Deacon JS R, Herrmann JPR and Opitz JM (1975) Familial Kallmann syndrome with unilateral renal aplasia. Clin Genet 7:368-381.

Weissortel R, Strom TM, Dörr HG, Rauch A and Meitinger T (1998) Analysis of an interstitial deletion in a patient with Kallmann syndrome X-linked ichthyosis and mental retardation. Clin Genet 54:45-51.

White BJ, Rogol AD, Brown SK, Lieblich JM and Rosen SW (1983) The syndrome of anosmia with hypogonadotropic hypogonadism: A genetic study of 18 families and a review. Am J Med Genet 15:417-435.

Woods-Samuels P, Kazazian HH Jr and Antonarakis SE (1991) Nonhomologous recombination in the human genome: Deletions in the human factor VIII gene. Genomics 10:94-101.

Zenteno LC, Mendez JP, Maya-Nunez G, Ulloa-Aguirre A and Kofman-Alfaro (1999) Renal abnormalities in patients with Kallmann syndrome. BJU Int 83:383-386.

Associate Editor: Angela M. Vianna-Morgante 